\title{
The Investigation of Nanoporous Structure Morphology and Elemental Composition of Organo-mineral Fertilizer Granules
}

\author{
A.E. Artyukhov, S.V. Vakal, A.O. Yanovska, V.Y. Shkola, V.S. Vakal, T.Y. Yarova
}

Sumy State University, 2, Rymsky-Korsakov St., 40007 Sumy, Ukraine

(Received 27 September 2020; revised manuscript received 15 December 2020; published online 25 December 2020)

\begin{abstract}
The structure of carbamide granules, which are encapsulated with an organic shell, is studied in this article. A schematic diagram of an experimental setup for producing organo-mineral fertilizers with a nanoporous shell is proposed. The use of a disk (pan) granulator to encapsulate mineral fertilizers with an organic nanoporous shell has been substantiated. The features of the structure of nanopores that allow to obtain an effective dissolution process of the shell and granule in the soil are presented. Nanoporous structure of the shell is uniform over the entire surface of the shell and occupies from 65 to $75 \%$ for different samples. The thickness of the shell in the different parts of the granule is uneven, which requires additional study and correction of the technological parameters of the process. The morphology of the shell's porous structure: rectilinear and curved nanopores, the depth of which ranges from 0.1 to 0.2 of the shell thickness. The pores in shell create a developed structure throughout the entire thickness of the shell, connecting with each other at different depths (thicknesses) of the shell. On the shell surface there is a certain amount of "mechanical" pores, which probably formed during the drying of the sample; the presence of such pores leads to the need to revise the thermodynamic characteristics of the drying process. The elemental composition of the granule core and shell has been studied in order to predict the process of penetration of shell elements into the core within the chosen encapsulation technology. The obtained results allow to improve the technology of obtaining encapsulated fertilizers in pan granulators. Based on the obtained data, it seems possible to improve the algorithm for constructive calculation of the pan granulator.
\end{abstract}

Keywords: Capsulation, Organo-mineral fertilizers, Nanoporous structure, Pan granulator, Morphology of the core and surface.

DOI: $10.21272 /$ jnep.12(6).06039

PACS numbers: 89.20.Bb, 89.20.Kk

\section{INTRODUCTION}

The capsulated organo-mineral fertilizers take a special place in the fertilizers classification for the agricultural sector [1-5]. This kind of fertilizers allows the introduction of various organic and inorganic elements into the soil, depending on the specific requirements of soils of particular regions [6-9].

One of the first and most significant steps in the practice of encapsulation technology is to determine the suitable coating substance as the material for encapsulation. This choice is depending on the active component and the acceptable properties of the final product. These characteristics can be reconciled concerning the physicochemical structure and latency of the material in the capsules, the encapsulated product's storage conditions, the scale and density of the materials to be coated in the process, and the economic cost of production [10-12].

For the production of organo-mineral fertilizers with the shell composition, which is discussed in this article, the most effective is the method of pelletizing in a pan granulator [13-15]. Unlike other methods of obtaining granular products (for example, described in works [16-20], where active hydrodynamic regimes are proposed to increase process intensity and other methods with different ways of granulation process intensification [21-23]), the pan granulator allows to obtain a viscous shell on the surface of the granule (core) of the organo-mineral fertilizer.

In general, the process of assimilation of organomineral fertilizers (Fig. 1) into the soil can be represented as follows:
- nutrients are released from the shell of each granule at the initial stage of dissolution;

- the elements are released due to the osmotic pressure of the soil;

- depending on the temperature and properties of the shell porous structure, the nutritive elements of the shell are released at a constant, regular and controlled rate;

- water penetrates into the shell and dissolves nutrients;

- after the shell is completely assimilated by the soil, the assimilation of the granule core begins.

The pore size of the shell and their structure affect the rate of water penetration from the soil into the shell, and then the granule core. Due to the presence of nanopores in the shell and interface, the dissolution of the organo-mineral fertilizer will occur from the shell to the core, which is the optimal way of fertilizer absorption. In the case of an increase in the pore size, water from the soil will penetrate into the granule in a larger amount, causing the simultaneous dissolution of both the shell and partially the core of the granule.

Besides, during the formation of the shell in a pan granulator and the subsequent heat treatment of the granule, due to the large pore size, the penetration of nutrients into the core of the granule is possible.

Within the framework of this article, the morphology of an organo-mineral fertilizer sample was investigated and the fact of penetration or non-penetration of nutrients from the shell into the core of the granule was established. Confirmation of the presence of a branched network of nanopores in the shell will allow to develop mechanisms for controlling the process of granule dissolution in soil in the future. 


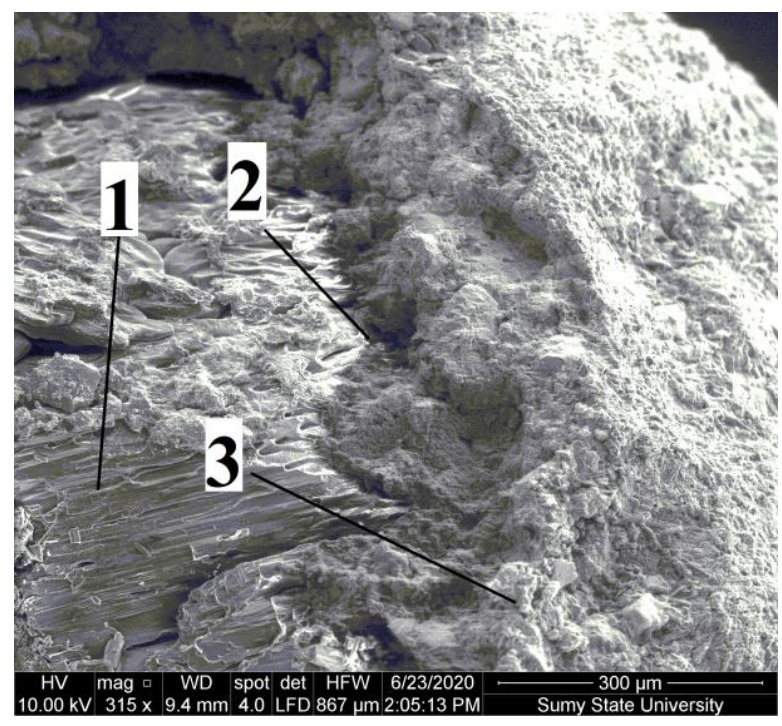

Fig. 1 - The sample of organo-mineral fertilizer: 1 - granule core; 2 - interface; 3 - shell

\section{DESCRIPTION OF OBJECT AND METHODS OF RESEARCH}

Fig. 2 demonstrates the experimental stand scheme for organic-mineral fertilizers production process. The general view of a pan granulator experimental sample is presented in Fig. 3.

The encapsulation process was carried out as follows. A phosphate-containing shell based on a phosphate-glauconite concentrate and a plasticizer was applied to the urea granule core, which contains calcium humate with the addition of microelements in the form of chelate compounds in an amount of 0.0002 $0.0005 \%$ to the granule mass. The shell formation process by agglomeration was realized in a pan granulator when feeding urea granules with a size of 2 $3 \mathrm{~mm}$, followed by moistening them with a plasticizer solution in an amount of $10-14 \%$ to the mass of phosphate-glauconite concentrate with simultaneous

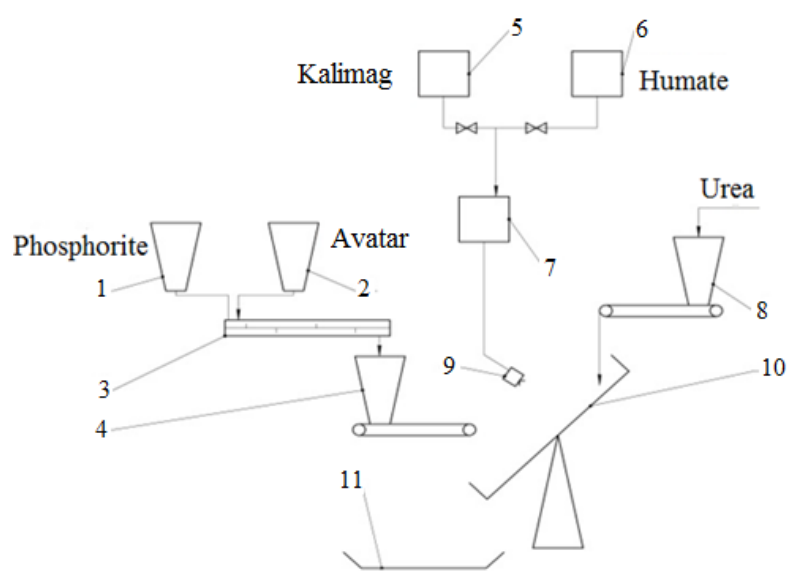

Fig. 2-Experimental stand scheme for organic-mineral fertilizers production process: 1 - phosphorite bunker; 2 bunker of microelements; 3 - mixer; 4 - dispenser; 5 potassium mg solution tank; 6 - humate solution tank; 7 potassium-magnesium mixing tank with humate; 8 - urea granules feed unit; 9 - nozzle; 10 - pan granulator; 11 - tray for granulated product

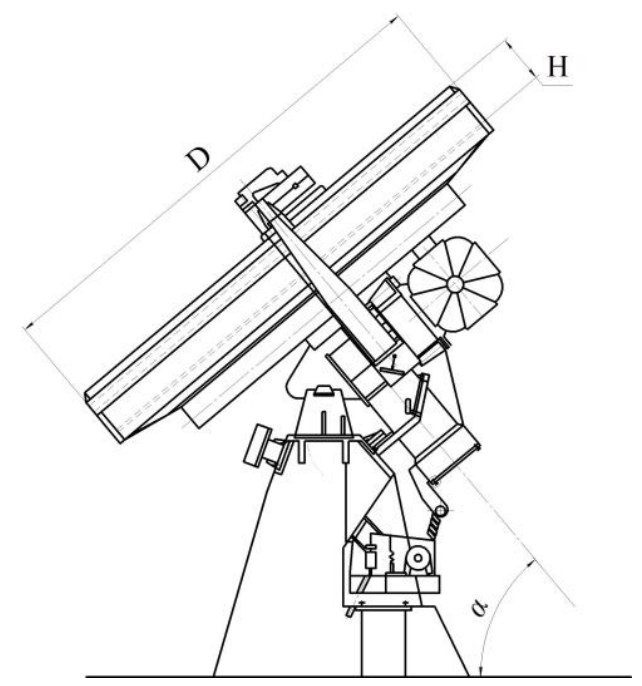

Fig. 3 - Pan granulator: $\mathrm{D}$ - diameter of the disc; $\mathrm{H}$ - height of the disc; $a$-tilt angle of the disc

feeding of powdered phosphate-glauconite concentrate to the moistened granules. Their particle size is nearly 200 microns at a ratio of the granule core mass and coating weight 1:(1.0-1.1), and drying of the formed granules occurs at a temperature of 64-66 degrees.

Physicochemical studies of the morphology and elemental composition of fertilizer samples were performed by scanning electron microscopy (SEM) with EDX analysis to assess the quality of the phosphatecontaining shell. During the analysis, the following morphological features were determined:

- the nanopores shape;

- the nanopores depth;

- the number of nanopores and the relative area of the nanoporous surface.

\section{RESULTS AND DISCUSSION}

The morphology of the shell structure of the organomineral fertilizer granule is shown in Fig. 4.

SEM morphology analysis of the granule shell made it possible to draw the following conclusions:

- the nanoporous structure is uniform over the entire surface of the shell and occupies from 65 to $75 \%$ for different samples; the thickness of the shell in the different parts of the granule is uneven, which requires additional study and correction of the technological parameters of the process;

- the morphology of the porous structure: rectilinear and curved nanopores, the depth of which ranges from 0.1 to 0.2 of the shell thickness;

- the pores create a developed structure throughout the entire thickness of the shell, connecting with each other at different depths (thicknesses) of the shell;

- on the shell surface there is a certain amount of "mechanical" pores, which are probably formed during the drying of the sample;

- the presence of such pores leads to the need to revise the thermodynamic characteristics of the drying process.

The interface structure of the capsulated granule is presented in Fig. 5. 


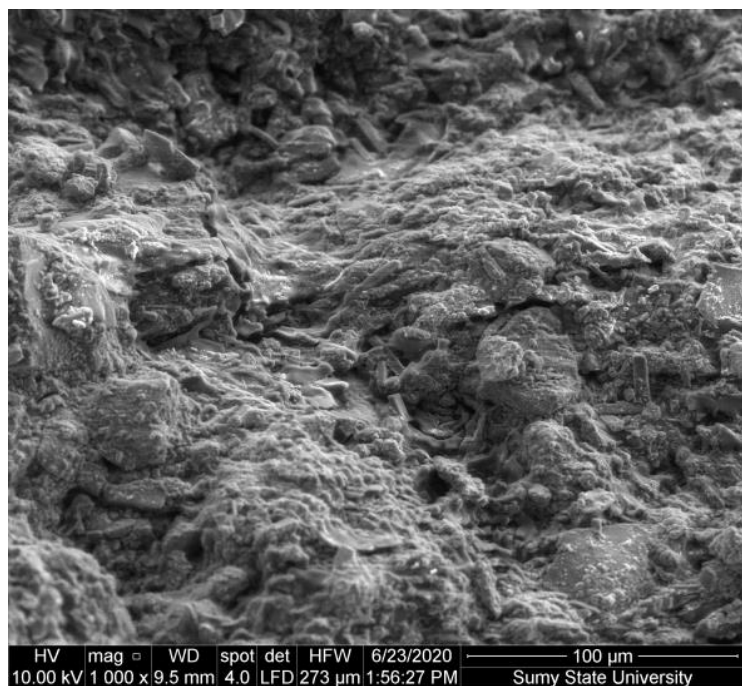

Fig. 4-Structure of the granule shell of organo-mineral fertilizers

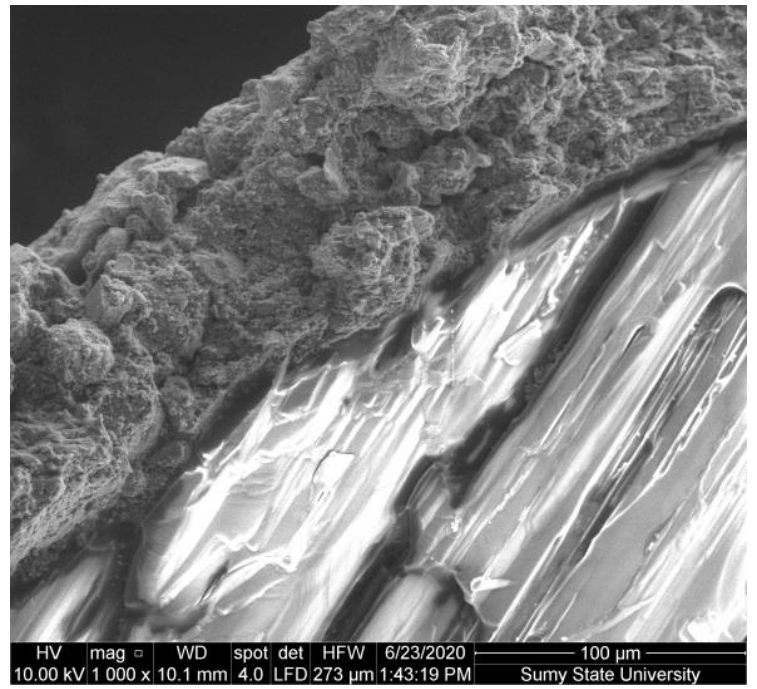

Fig. 5-Structure of the granule interface of organo-mineral fertilizer

Analysis of the granule interface morphology allowed us to draw the following conclusions:

- the shell is tightly attached to the granule core;

- morphology of the porous structure, namely rectilinear nanopores, and the pores create a developed structure along the entire interface; however, the nanoporous structure is no longer present on the core surface.

Analysis of the elemental composition (Fig. 6) shows the growth of $\mathrm{C}, \mathrm{N}$ in the right direction of the granule core. The granule core contains $\mathrm{O}, \mathrm{Al}, \mathrm{Si}, \mathrm{P}, \mathrm{K}, \mathrm{Ca}, \mathrm{Fe}$, $\mathrm{Mg}, \mathrm{S}, \mathrm{Na}$. The amount of $\mathrm{O}, \mathrm{Si}, \mathrm{P}, \mathrm{Mg}, \mathrm{Na}$ increased in the interface between the granule core and the shell comparing with elements amount in the shell. The amount of $\mathrm{Al}, \mathrm{K}, \mathrm{Ca}, \mathrm{Fe}, \mathrm{S}$ decreased from the top of the surface to the interface. Such elements like Al, P, K, $\mathrm{Fe}, \mathrm{Mg}, \mathrm{S}, \mathrm{Na}$ are absent in the internal layer.

\section{CONCLUSIONS AND RECOMMENDATIONS}

The obtained results showed that the encapsulation of urea granules within an organic shell in a pan granulator provides the following results:

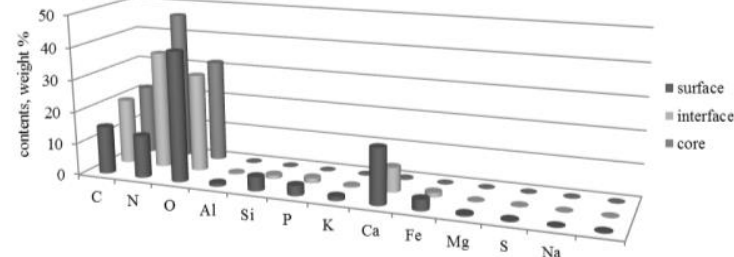

a

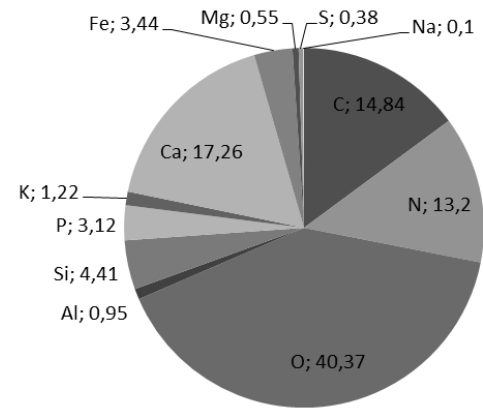

$\mathrm{b}$
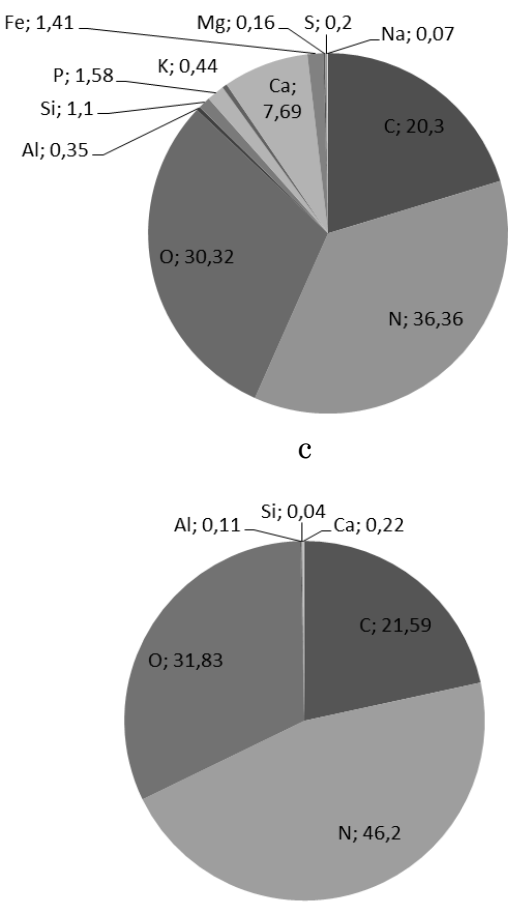

d

Fig. 6 - Elemental composition of organo-mineral fertilizer granules: a -general characteristics of changes in the composition of the granule from the shell to the core; the elemental composition of: $\mathrm{b}$ - the shell, $\mathrm{c}-$ the interface and $d$ - the core

- a developed nanoporous structure was created on the surface of the organic shell and through all its thickness;

- the main nutrients of the shell practically do not penetrate into the core granule;

- taking into account the difference in the composition of the shell and the granule, the assimilation of nutrients by the soil will occur uniformly and in a given time range, which is determined by the thickness of the shell and the diameter of the granule core; 
- it is necessary to clarify the technological parameters of the encapsulation process and subsequent drying in order to minimize the number of "mechanical" pores in the shell (especially on its surface). "Mechanical" pores (damage) together with the formed porous structure allow moisture to penetrate into the shell and dissolve it in the soil. However, major damage can cause the shell to peel off from the core of the pellet during transport, as well as premature dissolution of the shell in the soil due to the large amount of moisture that enters the shell. Additional destruction of the shell may be caused by a loose fit of the shell to the core of the granule.

The uniformity of the shell thickness of the granules is not a determining factor that affects the quality of fertilizer. The required amount of concentrate is applied to each granule according to the technological calculation. The main quality indicators are:

- the strength of granules and shells;

- the density of the shell to the granule and the adhesion of the shell to the surface of the granule;

- the developed porous structure with a minimum amount of mechanical damage to the surface caused by thermal stresses during drying.

\section{ACKNOWLEDGEMENTS}

This work was carried out under the project "Process of formation of the novel ecologically safe fertilizers with prolonged action based on the phosphorite deposits raw materials", project No. $0120 \mathrm{U} 102003$.

\title{
REFERENCES
}

1. A. Kuna, P. Achinna, Angrau. 38 No 1, 86 (2018).

2. C.A.C. Crusciol, M. de Campos, J.M. Martello, C.J. Alves, C.A.C. Nascimento, J.C. dos Reis Pereira, H. Cantarella, Sci. Rep. 10, 5398 (2020).

3. B.J. Zebarth, R. Chabot, J. Coulombe, R.R. Simard, J. Douheret, N. Tremblay, Canad. J. Soil Sci. 85 No 3, 387 (2005).

4. C.J. Dawson, J. Hilton, Food Pol. 36, S14 (2011).

5. G.L. Mumbach, L.C. Gatiboni, F.D. de Bona, D.E. Schmitt, J.C. Corrêa, C.A. Gabriel, D.J. Dall'Orsoletta, D.A. Iochims, Agronomy J. 112 No 4, 3037 (2020).

6. J.R. Rao, M. Watabe, T.A. Stewart, B.C. Millar, J.E. Moore, Waste Manage. 27, 1117 (2007).

7. H. Kominko, K. Gorazda, Z. Wzorek, Waste Biomass Valorization 8, 1781 (2017)

8. J.C. Corrêa, M.A. Grohskopf, R. da Silveira Nicoloso, K.S. Lourenço, R. Martini, Pesquisa Agropecuária Brasileira 51 No 8, 124 (2016).

9. M. Tejada, C. Benitez, J.L. Gonzalez, Agronomy J. 97, 960 (2004).

10. S.M. Jafari, Nanoencapsulation Technologies for the Food and Nutraceutical Industries. 1 (2017).

11. J.L. Oliverio, F.C. Boscariol, P.U. Mantelatto, Sugar Tech. 13 No 1, 17 (2011).

12. E. Ozturk, U. Temiz, Selcuk J. Agriculture Food Sci. 32 No 3, 624 (2018).

13. A. Heim, A. Obraniak, T. Gluba, Physicochem. Probl. Mineral Proces. 44 No 1, 53 (2010).

14. G.K. Reynolds, P.K. Le, A.M. Nilpawar, High Shear Granulation, Handbook of Powder Technology 11, 3 (2007).

15. P. Hoeung, Y. Bindar, S.P. Senda, Jurnal Teknik Kimia Indonesia 10 No 2, 102 (2011).

16. A. Artyukhov, N. Artyukhova, J. Environ. Health Sci. Eng. 16 No 2, 193 (2018).

17. A. Artyukhov, A. Ivaniia N. Artyukhova, J. Gabrusenoks, IEEE International Young Scientists Forum on Applied Physics and Engineering (YSF 2017), 315 (2017).

18. N. Artyukhova, J. Krmela, J. Nano- Electron Phys. 11 No 4, 04006 (2019).

19. N. Artyukhova, J. Nano-Electron Phys. 12 No 4, 04036 (2020).

20. A. Artyukhov, N. Artyukhova, A. Ivaniia, 14th International Conference on Advanced Trends in Radioelectronics, Telecommunications and Computer Engineering, TCSET 2018 - Proceedings, 139 (2018).

21. H. Stahl, Pharmaceutical Technology Europe 23 (2004).

22. H.K. Solanki, T. Basuri, J.H. Thakkar, C.A. Patel, International Journal of Pharmaceutical Sciences Review and Research. 5, No 3, 28 (2010).

23. J. Litster, B. Ennis, The Science and Engineering of Granulation Processes (Kluwer Academic Publishers: 2004).

\section{Дослідження морфології нанопористої структури і елементного складу гранул органо-мінеральних добрив}

\author{
А.Є. Артюхов, С.В. Вакал, А.О. Яновська, В.Ю. Школа, В.С. Вакал, Т.Ю. Ярова \\ Сулський державний університет, вул. Рилського-Корсакова, 2, 40007 Сули, Украйна
}

\begin{abstract}
Стаття присвячена вивченню структури гранул карбаміду, які капсульовані органічною оболонкою. Запропоновано принципову схему експериментальної установки для отримання органо-мінерального добрива з нанопористою оболонкою. Обгрунтовано застосування тарілчастого гранулятора для процесу капсулювання мінерального добрива органічною нанопористою оболонкою. Наведено особливості структури нанопор, які дозволяють забезпечити ефективний процес розчинення оболонки і гранули в грунті. Нанопориста структура оболонки рівномірна по всій поверхні оболонки і займає від 65 до $75 \%$ для різних зразків. Товщина оболонки в різних частинах гранули неоднакова, що вимагає додаткового вивчення та корекції технологічних параметрів процесу. Морфологія пористої структури оболонки: прямолінійні та криволінійні нанопори, глибина яких становить від 0,1 до 0,2 товщини оболонки. Пори в оболонщі створюють розвинену структуру по всій товщі оболонки, з'єднуючись між собою на різній глибині (товщині) оболонки. На поверхні оболонки є певна кількість “механічних» пір, які, ймовірно,
\end{abstract}


утворюються під час висихання зразка; наявність таких пор призводить до необхідності перегляду термодинамічних характеристик процесу сушіння. Вивчено елементний склад ядра і оболонки гранул з метою прогнозування процесу проникнення елементів оболонки в ядро при обраній технологіі капсулювання. Отримані дані дозволяють удосконалити технологію отримання капсульованих добрив в тарілчастих грануляторах. На основі отриманих даних представляеться можливим удосконалення алгоритму конструктивного розрахунку тарілчастого гранулятора.

Ключові слова: Капсулювання, Органо-мінеральні добрива, Нанопориста структура, Тарілчастий гранулятор, Морфологія ядра та поверхні. 